\title{
The utility of colonoscopy after acute appendicitis in those over 40 years
}

\author{
Umesh Jayarajah $^{1}$, Oshan Basnayake ${ }^{1}$, Sivasuriya Sivaganesh ${ }^{2}$ \\ ${ }^{1}$ Professorial Surgical Unit, National Hospital of Sri Lanka, Colombo, Sri Lanka \\ ${ }^{2}$ Department of Surgery, Faculty of Medicine, University of Colombo, Sri Lanka
}

Keywords: Acute appendicitis; colonoscopy; colorectal cancer; a systematic review

\begin{abstract}
\section{Introduction}

Acute appendicitis in older patients is less frequent and may be secondary to an underlying right colonic malignancy. This dictates the practice of performing colonoscopy in these patients after the resolution of appendicitis or appendicectomy, however, the evidence for this is limited. The objective of this study was to assess the utility of early colonoscopy (i.e. $<3$ months) to diagnose colonic cancer in older patients ( $>40$ years) following acute appendicitis.
\end{abstract}

\section{Methods}

PubMed, Embase, Cochrane Library and Google Scholar were searched using the search terms 'colonoscopy' OR 'malignancy' OR 'tumour' AND 'acute appendicitis'. Data regarding the proportion of older patients ( $>40$ years) after acute appendicitis who were detected to have a right colonic malignancy at follow-up colonoscopy within 3 months were analysed.

\section{Results}

The studies included patients from age 40-96 years (male:female=1.2:1). Colonoscopies were performed over a variable period of up to 3 years after appendicitis. None of the included studies addressed the main outcome measure sought. Instead, patients were followed up for periods ranging from 12-53 months. During this period, the incidence of colonic cancer ranged from $0.7-2.9 \%($ mean=1.7\%) which was considerably higher than that of the general population.

\section{Conclusions}

The risk of colorectal cancer development in this population over subsequent years appears to be higher than the general population. The utility of early colonoscopy in older patients after acute appendicitis is unclear from the available data and recommendations can only be made after appropriate

\footnotetext{
Correspondence: Sivasuriya Sivaganesh

E-mail: sivaganesh@srg.cmb.ac.lk

(i) https://orcid.org/0000-0002-6874-6904

Received: 03-08-2020 Accepted: 22-12-2020

DOI: http://doi.org/10.4038/sljs.v38i3.8723
}

prospective studies are done.

\section{Introduction}

Acute appendicitis is one of the commonest causes of an acute abdomen [1] with an estimated lifetime risk of $7.6 \%$ to $8.6 \%$ [2]. Though the majority of appendicectomies are performed in those below 40 years, about $30 \%$ are done in patients aged over 40 years [3]. Luminal obstruction by faecoliths, lymphoid hyperplasia, parasites or neoplasms at the appendicular base are believed to be mechanisms in the causation of acute appendicitis [4].

Conventional doctrine is that acute appendicitis in the elderly may be a harbinger of a caecal [5] or right colonic tumour [6]. The pathogenesis for this is thought to be luminal occlusion of the appendix by tumour infiltration, peri-tumoural inflammatory changes or raised intraluminal pressure in the caecum caused by a distal colonic neoplasm [7]. Moreover, the incidence of colon cancer is increasing in both developing and developed countries [8]. This logic leads to the practice of performing an early colonoscopy in those over 40 years following appendicectomy [9]. However, evidence and recommendations to support this practice are scarce, leading to a lack of consensus and variability in care pathways [10, 11]. Current guidelines anyway recommend population based endoscopic screening for colorectal cancer in those above the age of $50[12,13]$. This is pragmatic since in a normal population the detection rate of advanced adenomas in 40 - 49-year-olds is significantly less compared to the over 50 year-olds [12]. However, in patients after acute appendicitis in the corresponding age groups detection rates may be higher warranting early colonoscopy.

The objective of this systematic review was to validate the above practice by exploring the incidence of caecal or right colonic tumours detected by early colonoscopy (i.e. within 3 months) in older patients after acute appendicitis.

\section{Materials and methods}

PubMed, Embase, Cochrane Library and Google Scholar were searched using the search terms 'colonoscopy OR 'malignancy' OR 'tumour' AND 'acute appendicitis' in the title or abstract fields without any restriction on date limits. A nonEnglish language database, APAMED Central, was searched 
but did not reveal any studies relevant to the study question. The reference lists provided in full papers were also used to identify additional papers for review. The last date of the search was 31st March 2019. Both experimental and observational studies that considered the association of colonic neoplasms and acute appendicitis and the use of early colonoscopy (i.e. within 3 months) in older (more than 40 years) patients were included. Case reports were excluded from this review.

The title and abstracts were independently screened by two authors. Full texts of selected articles were reviewed, and eligible studies were identified. Data from individual studies were tabulated including the location of the study, basic demographic data of the patients, the use of colonoscopy and the percentage of malignancies detected during the follow up period. The primary outcome measure was the proportion of older patients detected to have a colonic malignancy on colonoscopy within 3 months of acute appendicitis. The secondary outcome was the overall incidence of colonic tumours in older patients following acute appendicitis.

Only a few studies observed the proportion of malignancies associated with acute appendicitis in the older population. There were no large scale prospective or case-control studies among them. They were mainly comprised of retrospective analyses and one prospective study.
Qualitative analysis was performed using the extracted data from the included studies and data were expressed as frequencies and percentages. A quantitative analysis (metaanalysis) could not be performed due to the study heterogeneity. Risk of bias analysis was performed according to the Downs and Black checklist and the findings are shown in table S1 [14].

\section{Results}

Forty-nine (49) studies found using the search strategy were screened for eligibility. The process of assessment and exclusion is summarised in the PRISMA flow chart (Figure 1). Only 11 studies were found to be suitable, analysing the proportion of colonic malignancies associated with acute appendicitis. Of these, 9 studies assessed the proportion of colonic malignancies detected immediately or subsequently after appendicectomy in patients over 40 years (Table 1 ) $[5,7$, 10, 11, 15-19]. Two large population based studies from Taiwan analysed the risk of developing a subsequent malignancy in patients of all ages in the 12 months follow up period after appendicectomy $[3,20]$.

Excluding the two large population based studies, there were 4555 appendicectomies reported in patients over 40 years (age range: 40-96 years). The mean patient age in individual studies ranged from $56-72$ years with a male to female ratio of 1.2:1.

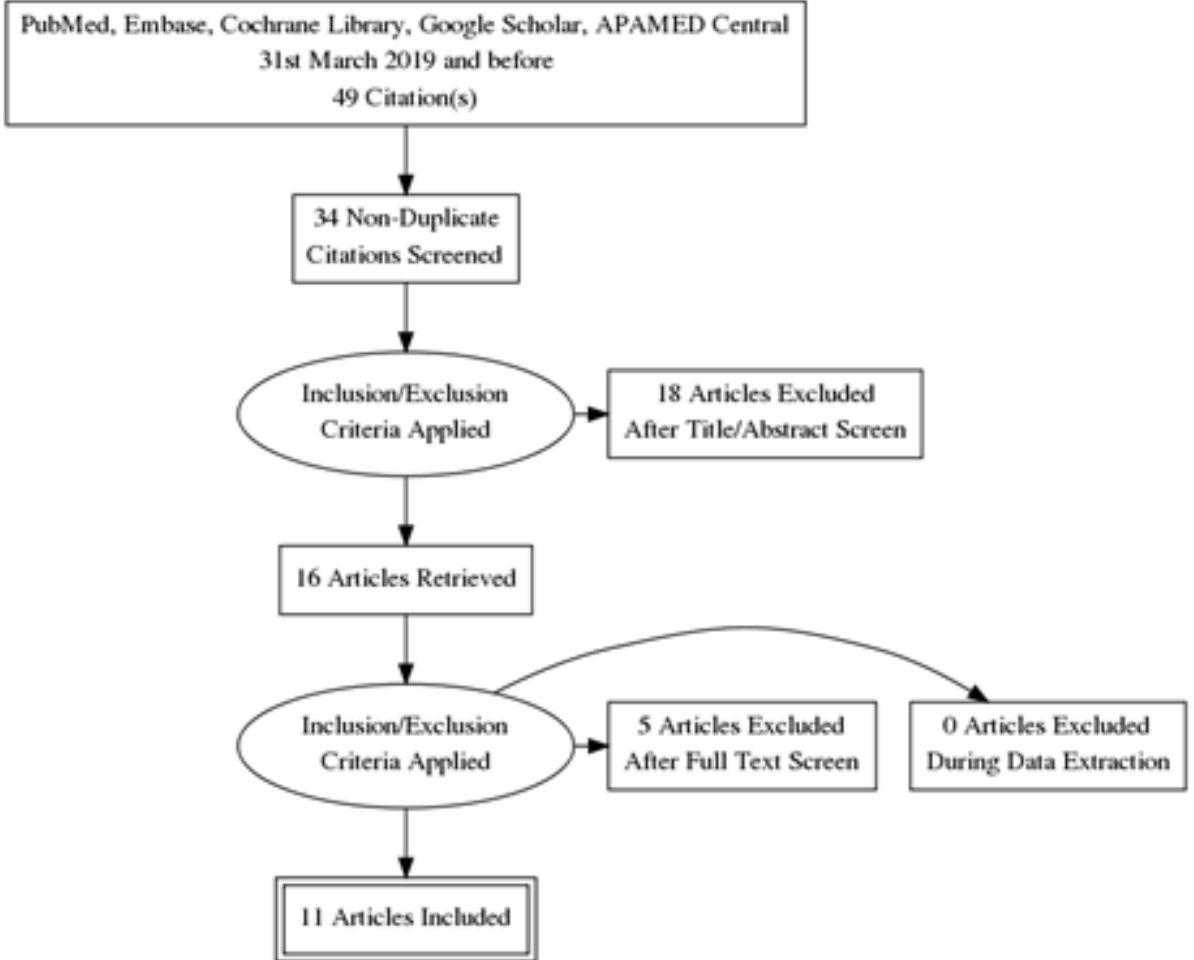

Figure 1. Prisma flow chart 
The proportion of patients over 40 years who had a colonoscopy after appendicitis was highly variable (1.1$100 \%$, within 2-3 years). Importantly, there were no studies that specifically addressed our primary outcome i.e. the detection of a caecal or colonic tumour at early colonoscopy (i.e. within 3 months) following acute appendicitis. However, a study by Lai et al detected colonic malignancies at or shortly after appendicitis using histology from intraoperatively detected tumours or subsequent computed tomography in others. Of the $16 / 1873(1.76 \%)$ patients who were found to have a colonic malignancy, 8 were detected in the first 4 months. Thus a proportion of $0.88 \%$ of older patients was found to have colonic cancer within the first 4 months following acute appendicitis. Studies from Sweden, Australia and Taiwan showed that those after appendicitis had a 6.3 38.5 fold increased risk of developing colorectal cancer compared to the general population (Table 1) $[10,11,16]$. The overall incidence of colonic tumours in elderly patients after appendicitis was $1.7 \%$ (range: $0.7-2.9 \%$ ) over a follow up period of 12 to 53 months. The 5 studies that compared the post-appendicectomy group to age and gender matched controls in the general population showed a considerably higher incidence of colorectal cancer in the former.

A large population study from Taiwan compared the incidence of colorectal cancer in the group following appendicectomy to that of the general population [20]. The overall incidence of colorectal cancer was $14 \%$ higher in the post-appendicectomy cohort compared to the general population of 1.5-3.5 years after appendicectomy with a hazard ratio of 2.13. Men were at higher risk than women [20]. A subsequent study by the same investigators compared 130,374 patients who underwent appendicectomy, with no previous diagnosis of cancer with a control group of 260,746 persons from the same database and assessed the incidence of malignancies within the subsequent year [3]. Interestingly, the study found a more than 4-fold increase in all cancers in the appendicectomy group over the control group (9.06 vs. 1.96 per 1000 person-months) with gastrointestinal and female genital tract malignancies accounting for $80 \%$ of the cancers. Furthermore, the hazard ratio was highest for female genital cancers followed by colorectal cancers, small intestinal cancers, pancreatic cancer and lymphomas.

A preponderance of right colonic malignancies was reported by most studies (Table 1). In contrast, the population based study from Taiwan showed that the incidence was highest for rectal cancers and lowest for caecal and ascending colon tumours in both the post-appendicectomy and general population [20].

Only one study performed a subgroup analysis between two age groups, i.e. $40-54$ years and 55 years and above. The study detected a caecal cancer rate of $1.6 \%$ in the 55 years and above age category while no malignancies were detected in the 40 54 years.

\section{Discussion}

The objective of this systematic review was to evaluate the utility of performing a colonoscopy within 3 months of acute appendicitis in patients above 40 years to detect a causative or associated caecal or colon cancer. However, there was no evidence in the literature available and reviewed to support this 'common sense' practice.

Whilst none of the studies describe the findings of early colonoscopy after appendicitis, several details the incidence of colorectal cancer in this cohort of patients in the subsequent 2 to 3 years. Though not the primary outcome measure of this study, it was interesting to note that the incidence of a subsequent colorectal malignancy was approximately $1.7 \%$ compared to $0.03-0.4 \%$ in the age matched normal population $[10,11]$. While this requires further prospective study, it raises the question of surveillance for colorectal cancer in this cohort of patients and the possible role of the appendix in colonic mucosal protection.

The pathophysiological basis for the correlation between a history of acute appendicitis or appendicectomy and subsequent colorectal cancer development requires clarification. Post-appendicectomy colonoscopy in the elderly is performed on the premise that either direct obstruction or peritumoral inflammation somehow initiates appendicitis.

However, this does not explain the increased incidence of cancer distributed along with the entire large bowel including the rectum noted in this study. More significant, though only described in the large population based Taiwanese study, is the observation of an increased incidence of extra-colonic tumours, especially female genital tract malignancies, in the post appendicectomy group. This raises interesting questions on the potential role of the appendix in tumour immunity. The appendiceal biofilm is believed to be beneficial to gut health [21] and the loss of the immunological functions of the appendix could be a plausible explanation for subsequent tumourigenesis. Furthermore, the previous appendicectomy was associated with a higher incidence of local fixity, abdominal wall invasion, poor differentiation and metastatic spread of colonic cancers [22]. It also was an independent risk factor for low survival rates and poor prognosis for patients who subsequently developed carcinoma of the caecum [22].

Most studies in this review showed the distribution of malignancies the following appendicectomy to predominate in the right colon. However, the population-based study from 
Table 1. Summary of findings of studies included in the systematic review

\begin{tabular}{|c|c|c|c|c|c|c|c|c|c|c|}
\hline Author & Year & Location & $\begin{array}{l}\text { Study } \\
\text { period }\end{array}$ & Study type & Design & $\mathbf{N}$ & $\begin{array}{l}\text { Colonos } \\
\text { copy }\end{array}$ & $\begin{array}{l}\text { Colorectal } \\
\text { cancer N } \\
\text { (96) }\end{array}$ & $\begin{array}{l}\text { Site of } \\
\text { turnour }\end{array}$ & $\begin{array}{l}\text { Comparison with } \\
\text { normal population }\end{array}$ \\
\hline Pedersen $^{5}$ & 2018 & Norway & $\begin{array}{l}2010- \\
2015\end{array}$ & $\begin{array}{l}\text { Retrospective } \\
\text { study }\end{array}$ & $\begin{array}{l}\text { Colonoscopy within } \\
3 \text { years after acute } \\
\text { appendicitis in } \\
\text { patients }>40 \text { years } \\
\text { of age }\end{array}$ & 731 & $\begin{array}{l}316 \\
(43.296)\end{array}$ & $9(1.2056)$ & $\begin{array}{l}\text { 4-caecum, 3- } \\
\text { ascending, 2- } \\
\text { rectum }\end{array}$ & NA \\
\hline Mustaev ${ }^{13}$ & 2015 & Australia & $\begin{array}{l}2002- \\
2014\end{array}$ & $\begin{array}{l}\text { Retrospective } \\
\text { study }\end{array}$ & $\begin{array}{l}\text { Colonoscopy within } \\
2 \text { years after acute } \\
\text { appendicitis in } \\
\text { patients }>50 \text { years } \\
\text { of age }\end{array}$ & 318 & $\begin{array}{l}63 \\
(19.896)\end{array}$ & $8(2.50 \%)$ & 7-right sided & NA \\
\hline $\mathrm{Lai}^{9}$ & 2006 & Taiwan & $\begin{array}{l}1998- \\
2003\end{array}$ & $\begin{array}{l}\text { Retrospective } \\
\text { study }\end{array}$ & $\begin{array}{l}\text { Patients }>40 \text { years } \\
\text { found to have colon } \\
\text { cancers immediately } \\
\text { or subsequently ( } 0 \text { - } \\
53 \text { months, median } \\
5.8 \text { months) after } \\
\text { appendectomy }\end{array}$ & 909 & NA & $\begin{array}{l}16(1.76 \%), \\
8(0.88 \%) \\
\text { within first } \\
4 \text { months }\end{array}$ & $\begin{array}{l}\text { 7-caecum, } \\
\text { 3-ascending } \\
\text { colon, } \\
\text { 2-transverse, } \\
\text { 2-sigmoid, 2- } \\
\text { rectum }\end{array}$ & $\begin{array}{l}\text { The odds ratio of } \\
\text { colon cancer incid-- } \\
\text { ence had a } 38.5- \\
\text { fold increase } \\
\text { among patients } \\
\text { older than } 40 \\
\text { years. (Incidence is } \\
\text { normal population- } \\
0.03 \% \text { ) }\end{array}$ \\
\hline Khan? & 2013 & Ireland & $\begin{array}{l}2005- \\
2011\end{array}$ & $\begin{array}{l}\text { Prospective } \\
\text { study }\end{array}$ & $\begin{array}{l}\text { Patients }>40 \text { years } \\
\text { were evaluated with } \\
\text { CT scan and } 2 \\
\text { underwent } \\
\text { colonoscopy }\end{array}$ & 179 & $2(1.1 \%)$ & $2(1.10 \%)$ & $\begin{array}{l}\text { 1-caecum, 1- } \\
\text { apendix }\end{array}$ & NA \\
\hline Shine ${ }^{10}$ & 2017 & Australia & $\begin{array}{l}2003- \\
2015\end{array}$ & $\begin{array}{l}\text { Retrospective } \\
\text { study }\end{array}$ & $\begin{array}{l}\text { Patients } \geq 45 \text { years } \\
\text { with appendicitis } \\
\text { were analysed to } \\
\text { find the rate of } \\
\text { colorectal } \\
\text { carcinoma diag- } \\
\text { nosed during the } \\
36 \text {-month follow-up } \\
\text { period }\end{array}$ & 541 & $\begin{array}{l}74 \\
\text { (1196) }\end{array}$ & $15(2.7096)$ & $\begin{array}{l}\text { 4-appendix, } \\
\text { 6-caecum, } \\
\text { ascending/tra } \\
\text { nsvers-2, } \\
\text { rectum/sigm } \\
\text { oid-2 }\end{array}$ & $\begin{array}{l}\text { 6.3-fold risk than } \\
\text { the normal } \\
\text { population. } \\
\text { (Incidence in the } \\
\text { age-matched } \\
\text { normal popular- } \\
\text { tion: } 0.486 \text { ) }\end{array}$ \\
\hline $\begin{array}{l}\text { Arnbjörns } \\
\operatorname{son}^{14}\end{array}$ & 1982 & Sweden & 1980 & $\begin{array}{l}\text { Retrospective } \\
\text { study }\end{array}$ & $\begin{array}{l}\text { Patients } \geq 40 \text { years } \\
\text { with appendicitis } \\
\text { were analysed to } \\
\text { find the rate of } \\
\text { colorectal } \\
\text { carcinoma diag- } \\
\text { nosed during the } \\
36 \text {-month follow-up } \\
\text { period }\end{array}$ & 561 & NA & $16(2.9096)$ & NA & $\begin{array}{l}29 \text {-fold risk than } \\
\text { normal age } \\
\text { matched } \\
\text { population. } \\
\text { (Incidence in the } \\
\text { age-matched } \\
\text { normal popul- } \\
\text { ation:0.196) }\end{array}$ \\
\hline Dhadlie ${ }^{15}$ & 2018 & Australia & $\begin{array}{l}2017- \\
2018\end{array}$ & $\begin{array}{l}\text { Retrospective } \\
\text { study }\end{array}$ & $\begin{array}{l}\text { Colonoscopy within } \\
2 \text { years after acute } \\
\text { appendicitis in } \\
\text { patients }>50 \text { years } \\
\text { of age }\end{array}$ & 43 & $\begin{array}{l}43 \\
{[100 \%)}\end{array}$ & $1(2.30 \%)$ & $\begin{array}{l}\text { 1-hepatic } \\
\text { flexure }\end{array}$ & NA \\
\hline Bizer $^{15}$ & 2013 & USA & $\begin{array}{l}1973- \\
1992\end{array}$ & $\begin{array}{l}\text { Retrospective } \\
\text { study }\end{array}$ & $\begin{array}{l}\text { Patients } \geq 65 \text { years } \\
\text { with appendicitis } \\
\text { were analysed to } \\
\text { find the rate of } \\
\text { concomitant caecal } \\
\text { or appendiceal } \\
\text { carcinoma }\end{array}$ & 218 & NA & $4(1.80 \%)$ & $\begin{array}{l}\text { all-caecal } \\
\text { cancer }\end{array}$ & NA \\
\hline $\begin{array}{l}\text { Mohamed } \\
17\end{array}$ & 2019 & UK & $\begin{array}{l}2004 \\
2014\end{array}$ & Retrospective & $\begin{array}{l}\text { Patients }>40 \text { years } \\
\text { with appendicitis } \\
\text { were analysed to } \\
\text { find the rate of } \\
\text { caecal pathology }\end{array}$ & 1055 & NA & $7(0.7 \%)$ & $\begin{array}{l}\text { All-caecal } \\
\text { cancer }\end{array}$ & NA \\
\hline $\begin{array}{l}\text { Wu }(a \| l \\
\text { cancers) }\end{array}$ & 2015 & Taiwan & $\begin{array}{l}2000- \\
2009\end{array}$ & $\begin{array}{l}\text { Retrospective } \\
\text { population- } \\
\text { based study }\end{array}$ & $\begin{array}{l}\text { 130,374 patients (all } \\
\text { ages) newly } \\
\text { received } \\
\text { appendectomy from } \\
2000-2009 \text {, without } \\
\text { cancer were } \\
\text { compared with a } \\
\text { control sample of }\end{array}$ & 130374 & NA & $446(0.3486)$ & NA & $\begin{array}{l}\text { HR of } 14.7 \text { (8.66- } \\
25.0 \text {. Incidence in } \\
\text { the control } \\
\text { group: } 0.038 \% \text { ) }\end{array}$ \\
\hline
\end{tabular}




\begin{tabular}{|c|c|c|c|c|c|c|c|c|c|c|}
\hline & & & & & $\begin{array}{l}260,746 \text { persons } \\
\text { and the risk of } \\
\text { development of } \\
\text { cancer in the next } \\
12 \text { months was } \\
\text { calculated }\end{array}$ & & & & & \\
\hline $\begin{array}{l}\text { Wu }{ }^{18} \\
\text { (colorecta } \\
\text { I cancers) }\end{array}$ & 2015 & Taiwan & $\begin{array}{l}1997- \\
1999\end{array}$ & $\begin{array}{l}\text { Retrospective } \\
\text { population- } \\
\text { based study }\end{array}$ & $\begin{array}{l}75979 \text { patients who } \\
\text { underwent } \\
\text { appendectomy } \\
\text { between } 1997 \text { and } \\
1999 \text { were } \\
\text { compared with age, } \\
\text { sex and comorbidity } \\
\text { matched } 303640 \\
\text { persons without } \\
\text { appendectomy and } \\
\text { subsequent } \\
\text { colorectal cancer } \\
\text { incidence was } \\
\text { studied }\end{array}$ & 75979 & NA & $375(0.49 \%)$ & $\begin{array}{l}\text { 7-Caecum- } \\
\text { ascending } \\
\text { colon, } \\
\text { 24-hepatic } \\
\text { flexure- } \\
\text { transverse } \\
\text { colon, } \\
\text { 11-splenic } \\
\text { flexure- } \\
\text { descending } \\
\text { colon, } \\
\text { 48-sigmoid, } \\
\text { 159-rectum, } \\
63 \text {-others, } \\
63 \text {-mixed }\end{array}$ & $\begin{array}{l}\text { The incidence of } \\
\text { colorectal cancer } \\
\text { was higher in } 1.5 \text { - } \\
3.5 \text { years post } \\
\text { appendectomy } \\
\text { follow-up than for } \\
\text { the comparisons } \\
\text { (HR of } 2.13 \text { ) }\end{array}$ \\
\hline
\end{tabular}

Table 2. Availability of information in the studies included in relation to the objective of the systematic review

\begin{tabular}{|c|c|c|c|c|c|}
\hline Author & $\begin{array}{l}\text { Colonoscopy } \\
\text { within } 3 \text { months } \\
\text { mentioned }\end{array}$ & $\begin{array}{l}\text { Subgroup } \\
\text { analysis of } \\
\text { age given }\end{array}$ & $\begin{array}{l}\text { Proportion of } \\
\text { patients who } \\
\text { underwent } \\
\text { colonoscopy given }\end{array}$ & $\begin{array}{l}\text { Distinction } \\
\text { between caecal, } \\
\text { and other } \\
\text { tumours given }\end{array}$ & $\begin{array}{l}\text { Comparison with } \\
\text { general } \\
\text { population given }\end{array}$ \\
\hline Pedersen $^{5}$ & No & No & Yes & Yes & No \\
\hline Mustaev ${ }^{13}$ & No & No & Yes & No & No \\
\hline $\mathrm{La}^{9}$ & No & No & No & Yes & Yes \\
\hline Khan $^{7}$ & No & No & Yes & Yes & No \\
\hline Shine $^{10}$ & No & No & Yes & Yes & Yes \\
\hline Arnbjörnsson ${ }^{14}$ & No & No & No & No & Yes \\
\hline Dhadlie ${ }^{15}$ & No & No & Yes & Yes & No \\
\hline Bizer ${ }^{16}$ & No & No & No & Yes & No \\
\hline Mohamed 17 & No & Yes & No & Yes & No \\
\hline$W^{3}$ (all cancers) & No & No & No & No & Yes \\
\hline $\begin{array}{l}\text { Wu1s (colorectal } \\
\text { cancer) }\end{array}$ & No & No & No & No & Yes \\
\hline
\end{tabular}


Taiwan [20], showed a higher incidence of rectal cancer compared to right colonic tumours. This may reflect the inherently higher incidence of rectal tumours compared to right colonic malignancies in the general population [23, 24]. However, the reason for the discrepancies is not clear and requires further study.

\section{Limitations}

Most studies were retrospective and included small numbers. Only 5 studies mentioned the proportion of patients undergoing subsequent colonoscopies (Table 2). In the limited number of patients who underwent colonoscopy in the follow-up period the indication or selection criteria was not documented. Only 7 studies made the distinction between caecal and other tumours. Studies included patients detected to have cancer over a variable subsequent period of 12-53 months and therefore it may be possible to have included patients who developed cancer at a later stage. Subgroup analysis of different age categories was not possible with the available information as only one study had looked at it [19]. Some studies did not clarify the mode of colonic tumour detection, i.e. whether it was following investigation of symptoms or during screening. A meta-analysis was not done due to the heterogeneity of the selected studies.

\section{Conclusions}

The utility of early colonoscopy in older patients after acute appendicitis is uncertain from available data in this study and recommendations can only be made after prospective studies are done. Despite the absence of clear evidence, we believe it would be sensible to proceed with an early check colonoscopy in this cohort, considering that their numbers are anyway likely to be small.

Interestingly, the subsequent risk of developing colorectal cancer and possibly some extra-colonic cancers in this older group of post-appendicectomy patients appears to be considerably higher (approximately 1.7\%) than the general population. Through this systematic review ultimately could not address the primary question about the importance of early colonoscopy in older patients after acute appendicitis, it revealed a possible association between acute appendicitis and subsequent increased risk of colorectal and extracolonic malignancies. This warrants further investigation so that recommendations on long-term colonoscopic surveillance and in cases of extra-colonic neoplasms other modes of surveillance may be considered. Besides, it warrants further study of the role of the appendix in tumour immunity.

This study was published as an abstract at Asia Pacific Digestive Week 2019 [25].
All authors disclose no conflict of interest. The study was conducted in accordance with the ethical standards of the relevant institutional or national ethics committee and the Helsinki Declaration of 1975, as revised in 2000 .

\section{References}

1. Markar SR, Penna M, Harris A: Laparoscopic approach to appendectomy reduces the incidence of short-and long-term post-operative bowel obstruction: systematic review and pooled analysis. Journal of Gastrointestinal Surgery 2014, 18(9):16831692.

https://doi.org/10.1007/s11605-014-2572-7

2. Addiss DG, Shaffer N, Fowler BS, Tauxe RV: The epidemiology of appendicitis and appendectomy in the United States. American journal of epidemiology 1990, 132(5):910-925. https://doi.org/10.1093/oxfordjournals.aje.a115734

3. Wu SC, Chen WT, Muo CH, Sung FC: Appendicitis as an early manifestation of subsequent malignancy: an asian population study. PloS one 2015, 10(4):e0122725.

https://doi.org/10.1371/journal.pone.0122725

4. Collins D C: A study of 50,000 specimens of the human vermiform appendix. Surgery, gynecology \& obstetrics 1955, 101:437-445. https://pubmed.ncbi.nlm.nih.gov/13256319/

5. Sylthe Pedersen E, Stornes T, Rekstad LC, Martinsen TC: Is there a role for routine colonoscopy in the follow-up after acute appendicitis? Scandinavian journal of gastroenterology 2018, 53(8):1008-1012.

https://doi.org/10.1080/00365521.2018.1485732

6. Burt C: Carcinoma of the cecum complicated by appendicitis or para-cecal abscess. Surgery, gynecology \& obstetrics 1949, 88(4):501-508.

https://pubmed.ncbi.nlm.nih.gov/18113319/

7. Khan S A, Khokhar H A, Nasr A, Carton E: Incidence of rightsided colonic tumors (non-appendiceal) in patient's $\geq 40$ years of age presenting with features of acute appendicitis. International journal of surgery 2013, 11(4):301-304.

https://doi.org/10.1016/j.ijsu.2013.02.004

8. Jayarajah U, Udayanga V, Fernando A, Samarasekera DN, Seneviratne $S$ : The incidence and patterns of colorectal cancers in Sri Lanka from 2001 to 2010: Analysis of national cancer registry data. European Journal of Cancer Care 2020:e13247. https://doi.org/10.1111/ecc.13247

9. Haggar FA, Boushey RP: Colorectal cancer epidemiology: incidence, mortality, survival, and risk factors. Clinics in colon and rectal surgery 2009, 22(4):191.

https://doi.org/10.1055/s-0029-1242458

10.Lai HW, Loong CC, Tai LC, Wu CW, Lui WY: Incidence and odds ratio of appendicitis as first manifestation of colon cancer: a retrospective analysis of 1873 patients. Journal of gastroenterology and hepatology 2006, 21(11):1693-1696. https://doi.org/10.1111/j.1440-1746.2006.04426.x

11.Shine RJ, Zarifeh A, Frampton C, Rossaak J: Appendicitis presenting as the first manifestation of colorectal carcinoma: a 13-year retrospective study. Ethnicity 2017, 299:47.45. https://pubmed.ncbi.nlm.nih.gov/28727691/ 
12.Rex DK, Boland CR, Dominitz JA, Giardiello FM, Johnson DA, Kaltenbach T, Levin TR, Lieberman D, Robertson DJ: Colorectal cancer screening: recommendations for physicians and patients from the US Multi-Society Task Force on Colorectal Cancer. Gastroenterology 2017, 153(1):307-323. https://doi.org/10.1053/j.gastro.2017.05.013

13.Jayarajah U, Fernandopulle N: Quality measures for lower gastrointestinal endoscopy: a review of recent consensus statements and guidelines. Sri Lanka Journal of Surgery 2019, 37:24-31. https://doi.org/10.4038/sljs.v37i4.8657

14.Downs SH, Black N: The feasibility of creating a checklist for the assessment of the methodological quality both of randomised and non-randomised studies of health care interventions. Journal of Epidemiology \& Community Health 1998, 52(6):377-384. https://doi.org/10.1136/jech.52.6.377

15.Mustaev M, Naseem Z, Mizumoto R, Mehanna D, Ratnayake S, Shekhar A, Lai NK: "Do we have to do it?" Role of early colonoscopy after appendicectomy in the elderly: A singlecentre experience. Surgery: Current Research 2015, 5:7 https://doi.org/10.4172/2161-1076.C1.021

16.Arnbjornsson E: Acute appendicitis as a sign of a colorectal carcinoma. Journal of surgical oncology 1982, 20(1):17-20. https://doi.org/10.1002/jso.2930200105

17.Dhadlie S, Mehanna D: Rates of colorectal cancer detection in screening colonoscopy post appendicectomy in patients 50 years and over. Annals of medicine and surgery 2018, 36:239-241. https://doi.org/10.1016/j.amsu.2018.11.012

18.Bizer LS: Acute appendicitis is rarely the initial presentation of cecal cancer in the elderly patient. Journal of surgical oncology 1993, 54(1):45-46. https://doi.org/10.1002/jso.2930540112

19.Mohamed I, Chan S, Bhangu A, Karandikar S: Appendicitis as a manifestation of colon cancer: should we image the colon after appendicectomy in patients over the age of 40 years? Int $\mathrm{J}$ Colorectal Dis 2019, 34(3):527-531.

https://doi.org/10.1007/s00384-018-03224-8

20.Wu S-C, Chen WT-L, Muo C-H, Ke T-W, Fang C-W, Sung F-C: Association between appendectomy and subsequent colorectal cancer development: an Asian population study. PloS one 2015, 10(2):e0118411.

https://doi.org/10.1371/journal.pone.0118411

21.Kooij IA, Sahami S, Meijer SL, Buskens CJ, Te Velde AA: The immunology of the vermiform appendix: a review of the literature. Clinical and experimental immunology 2016, 186(1):1-9. https://doi.org/10.1111/cei.12821

22. Armstrong CP, Ahsan Z, Hinchley G, Prothero DL, Brodribb AJ: Appendicectomy and carcinoma of the caecum. The British journal of surgery 1989, 76(10):1049-1053.

https://doi.org/10.1002/bjs.1800761022

23.Lee GH, Malietzis G, Askari A, Bernardo D, Al-Hassi HO, Clark SK: Is right-sided colon cancer different to left-sided colorectal cancer? - A systematic review. European Journal of Surgical Oncology (EJSO) 2015, 41(3):300-308.

https://doi.org/10.1016/j.ejso.2014.11.001

24.Bretthauer M, Kaminski MF, Løberg M, Zauber AG, Regula J, Kuipers EJ, Hernán MA, McFadden E, Sunde A, Kalager M: Population-based colonoscopy screening for colorectal cancer: a randomized clinical trial. JAMA internal medicine 2016, 176(7):894-902.

https://doi.org/10.1001/jamainternmed.2016.0960

25.Jayarajah U, Basnayake O, Nagodavithane K, Sivaganesh S: The utility of colonoscopy after acute appendicitis in those over 40 years: a systematic review. Journal of Gastroenterology and Hepatology 2019, 34(S3):82-82. https://doi.org/10.1111/jgh.14879 